\title{
55. インバータ式メ線高電圧装置の特性

\author{
Characteristics of the Inverter High Voltage X-ray Generator
}

東邦大学医学部付属大橋病院放射線部 0 宮崎, 茂 松谷一雄铪木紀子

(S. Miyazaki) (K. Matutani) (N. Suzuki)

〔緒言〕インバー夕式X線高電圧装置が国内で製 品かされ9年が過ざようとしている。この間装置 の准步は著しいものがあるが撮影技術の見地から X線出为の特性を考之ると多くの問題を抱えてい た。この中からインバー夕周波数最大 $30 \mathrm{k} \mathrm{Hz}$ 共振形X線装置の短時間特性、管電圧脈動率及び 管電流によるX線出力の直線性に付いて検討した ので報告する。

[測定結果〕

(1) 短時間特性：短時間撮影時におけ引 X線出 力の直線性について測定した結果を図 1 に示す。 横軸に撮影時間、維軸に撮影時間 $64 \mathrm{~m} \mathrm{~s}$ の出力 を100\%としたしきの割合である。これから理 想的な装固は直線となる。撮影時間 $10 \mathrm{~ms}$ 以下 からX線出力は增加の傾向を示し最短撮影時間で は130\%であった。

非直線性の傾向はX線真荷による影響をほとんど 受けない。

(2) 管電圧脈動率 : X線賁荷を変之脈動率の変 動を調心た結果を表 1 に示寸。最少 1 ．9\%、最 大 $6.8 \%$ の脈動率で范った。

（３）管電流特性：管電流少少なくなる侻い出 力は僅かである师增加の傾向を示し直線性は失わ れ、その傾向は高管電圧になる程顯著に表记る。

[考察]图 2 は管電压 $60 ， 100 \mathrm{kV}$ 管電流 $50,500 \mathrm{mAO}$ 管電生、管電流、螢光強度波

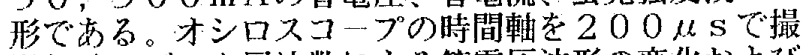
影しイシバー夕周波数による管電圧波形の変化抢よび 立ち上がり時間を明確にする目的で湘定したものである。 (1) 短時間特性：X線出力の非值線性は管電压の立. ち上がり、立ち下がり時間に起因守るもので短洔間ほ ど大きくなる今回測定した装置の立ち上がり時間は $0.65 \mathrm{~ms}$ と非常に速いが撮影時間 $10 \mathrm{~ms}$ 以下名 ら直線性は無くなる。この原因は管電压の立占上がり 立ち下がり時間よりむしろ撮影時間溰差によるもので 短時間ほど誤差は大きい(表2)。

(2) 管電圧脈動率 : 軽真荷ではインバー夕周波数は 約 $3 \mathrm{k} \mathrm{Hz}$ 乙低下寸るため脈動率は $6.8 \%$ 大きく なるが脈動す当管電圧は急俊なことから出力に与える 影響は少ない。

(3) 管電流特性 : 高管電压、低管電流で若干X線出 力は増加し非直線性を示すがこの原因は高電压ケ-ブ ルの浮游用量に因るものと考之られる。

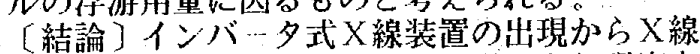
出力の再現性が高まり短時間撮影はより現実な ものとなってきた。X線高電死装置と組み合 わせるX線管装置などの問題は残るが今回測 定した装置は管電压の立ち上がり時間は

0. $65 \mathrm{~ms}$ 速く矩形波に近いこと加らよ り一步短時間撮影が身近になったものと考える。

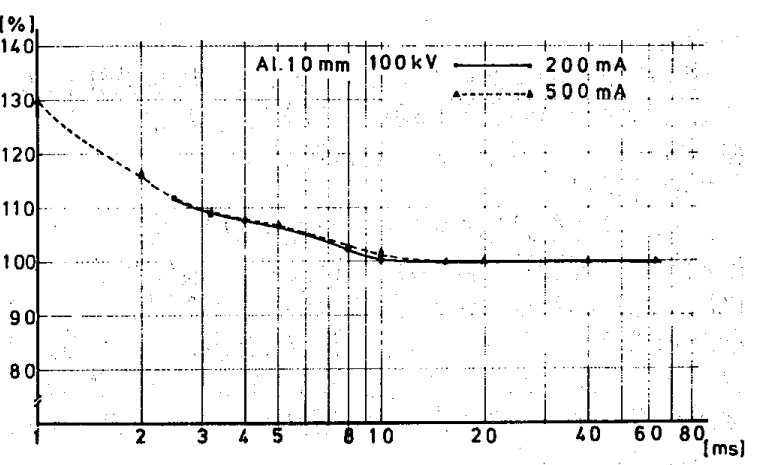

図 1

\begin{tabular}{r|r|r|r|r}
$\mathrm{mA}^{\mathrm{kV}}$ & 60 & 80 & 100 & 120 \\
\hline 50 & 6.8 & 4.7 & 3.4 & 2.5 \\
\hline 100 & 5.3 & 3.7 & 2.9 & 1.9 \\
\hline 200 & 4.5 & 2.9 & 2.2 & 2.1 \\
\hline 400 & 3.8 & 2.8 & 2.6 & 2.5 \\
\hline 500 & & 3.4 & 2.9 & 2.4 \\
\hline
\end{tabular}

(\%)

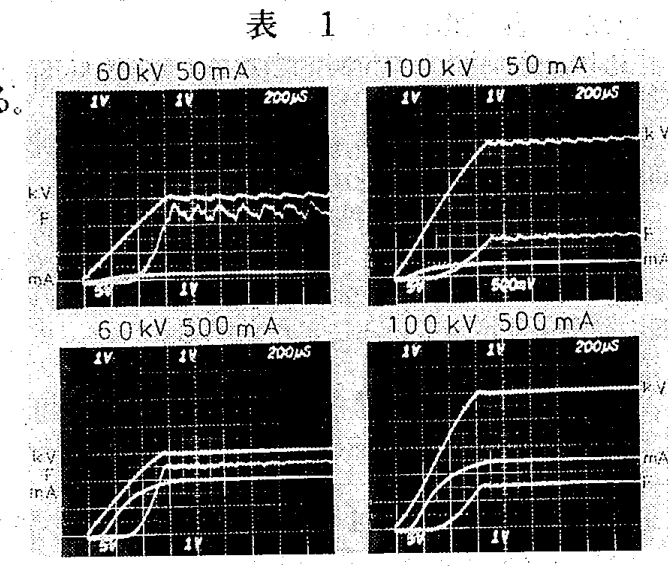

图 2
$100 \mathrm{kV} \quad 200 \mathrm{~mA}$

\begin{tabular}{lllllll}
\hline 表示值 & 2.5 & 3.2 & 4.0 & 5.0 & 8.0 & 10.0 \\
洞定值 & 3.0 & 3.7 & 4.5 & 5.4 & 8.3 & 10.1 \\
\hline & & & & & &
\end{tabular}

